\title{
Is halal certificate socialization effective in increasing the number of MSMEs in the food sector to register for halal certificates?
}

\author{
M. Puspaningtyas \\ Universitas Negeri Malang, Malang, Indonesia
}

\begin{abstract}
The purpose of this research is to provide knowledge and application to The Owner of SMEs to register their products at the health office so as to get halal labels. Halal food is an important requirement for the advancement of local food products in Indonesia to compete with other products both at home and abroad. Indonesia is a country with a majority Muslim population. Based on the presentation of the results and discussion above, it can be concluded from the service activity that awareness exists of the importance of the ownership of letters, which significantly supports business strengthening. Business actors are very enthusiastic about participating in counseling activities about the ownership of halal certificates.
\end{abstract}

Keywords: halal, register, small-medium-enterprise

\section{INTRODUCTION}

Indonesia is a country with many Islamic religions that dominate the religious population statistics. $87.2 \%$ or as many as 207 million people are Muslims (Indonesia.go.id). For Muslims, it is essential to know whether the food is lawful or not. Because according to Islamic law, the importance of food should be considered. As it appears in the Holy Qur'an the letter of Al-Baqarah (168-171) reads: "O people eat what is clean and good that is on the earth, and do not follow in the steps of Satan. Because indeed Satan is a real enemy to you. (169) Indeed, the devil only orders you to do evil and wickedness and tells Allah what you do not know. (170) And when it is said to them: 'Follow what Allah has sent down,' and they answer: '(No), but we only follow what we have found from the (deeds of) our ancestors.' '(Will they follow too), even though their ancestors did not know anything, and didn't get a clue?' (171) And the parable (of the one calling) the disbelievers is like the shepherd who calls the beast who hears nothing but calls and cries. They are deaf, dumb, and blind, so (therefore) they don't understand." (Al-Baqarah, 168-171).

Fulfillment of halal guarantees must be made to meet food production standards while protecting consumers. Etymologically, halal is known as "halla" which means "off" or "not tied". Halalan is anything that is allowed and is not bound by various provisions. Tayyib means "delicious, good, healthy, reassuring". Meanwhile, if the food is good and not dirty, both from the substances it contains and is not mixed with unclean objects, it is known as tayyib (Girindra 2008). According to Regulation of Constitutions number 8, the year 1999 concerning Consumer Protection explains consumer protection exists to provide benefits, fairness, balance, security and consumer safety, and legal certainty. Furthermore, Regulation of Constitutions number 7, the year 1996, concerning Food, article 30 paragraph (1) and (2) stipulates that every person who manufactures or imports Indonesian food packaged for trade must include a halal label so that consumers avoid consuming non-halal products. The purpose of enacting the necessity of food entrepreneurs to give a halal label on each product is to help increase consumer confidence in the quality of the food product. When consumers have given their trust in a product, consumers will tend to choose products that are believed to be of quality. Indirectly, sales of Micro, Small, and Medium Enterprise (MSME) 
products will increase and grow. Hard work is needed in realizing a thriving business. Various kinds of efforts need to be made by business owners to promote their products.

According to the Chairperson of the Indonesian Ulama Council (MUI), KH. Ma'rufAmin inopening the 2018 International Indonesia Halal Expo (INDHEX) explained that halal certification becomes the strength of small-medium-enterprise competitiveness because consumer demandsfor halal food availability are increasing. Halal certification becomes important for food producers due to several things, such as guaranteed halal food products, the product is more trusted by the people, benefit from the marketing side, the more convincing the consumer, considers it too important for halal not located on the label. While food manufacturer information on halal certification is obtained using several ways, such as print and electronic media, BPOM, Ministry of Health, seminars, relatives or friends, and based on the labels on the packaging. The question that arises over the many socializations that are often carried out is "how much of the socialization's effectiveness is required for the realization of MSME actors to register themselves to get a halal certificate for their business?"

The reality shows that there are so many new Micro, Small, and Medium Enterprises (MSME) emerging every year. The latest data from www.dekop.go.id (2019) shows an increase of $2.02 \%$ in the 2017-2018 timeframe. However, the increase in the number of SMEs is still far behind the number of halal-certified products. Data obtained from halalmui.org states that in 2018 there were only 204,222 products and 11,249 companies that were halal certified. In 2019, the number of MSMEs with halal certification increased by 274,796 products and 13,951 companies (halalmui.org 2019). Unfortunately, this increase has not shown a significant value because when compared to the number of Micro, Small, and Medium Enterprise (MSME), the percentage is very small each year.

Based on the description above, we need an activity that is right on target to create food that is safe and does not make Muslims still wonder about the halal nature of the food. Thus, this community service activity with the theme of Halal Certificate Education and P-IRT for Food Products at SMEs throughout Blitar Raya. This community service activity aims to motivate the community of entrepreneurs to have a strong foundation in running their business. This activity is carried out to socialize the importance of the P-IRT number in ensuring the business's continuity and quality and the benefits of halal certificates as the selling power of the product. From the academic perspectives, this study may contribute to other researchers as their main references regarding the study on educating SMEs about Halal certification's importance.

\section{LITERATURE REVIEW}

Halal products contain goods or services related to food, beverages, medicines, cosmetic chemical products, or biological products, as well as users of goods that are used by the community. The halal product process is a series of activities to ensure that a product comes from providing materials, processing, storing, packaging distribution, selling, and presenting the product in a good way. The guarantee of a halal product requires a system that contains halal assurance, both in terms of raw materials and their derivatives as well as from the production process. Foods that are fit for consumption consist of quality elements. The quality of food is not just about its looks, texture, and taste. In the halal concept, quality food includes its hygiene and wholesomeness, and these are among the factors lacking in small-medium enterprises especially when they want to adopt halal (Backhouse \& Mohamad 2014). The halal guarantee system (SJH) is a system created and implemented by companies holding halal certificates to ensure the halal production process's sustainability. This system is made into part of a stand-alone system's policy so that the resulting product can be guaranteed halal following the rules outlined by LPPOM-MUI (Hasan 2018).

MUI halal certificate is a requirement to obtain permission to put halal labels on product packaging from authorized government agencies. Producers guarantee the halal production process's continuity by implementing the Halal Assurance System (www.halalmui.org). The halal certification process is a series of procedures for obtaining halal certificates for products to be marketed. In 
line with the statement, some scholars stated that the foodservice industry had some challenges in halal food certification (Kurth \& Glasbergen 2017). Among the challenges include cost (Rahman et al. 2016), lack of government support (Shafie \& Othman 2006), and awareness (Ngah et al. 2015). However, according to Salikin et al. (2014), adopting a quality certification requires more than cost, support, and awareness. It requires motivation (Koryak et al. 2015) and knowledge.

Additionally, many studies have focused on halal awareness and perception (Elias et al. 2016), halal certification (Sulaiman et al. 2016), and halal supply chain (Soon et al. 2017). Thus, knowledge in the motivational factors influencing the adoption of halal certification in the small and micro-enterprise are still scarce. This study could improve knowledge and help the government in introducing a policy to encourage these companies to embark on the halal journey (Basir et al. 2018). Halal products can convince consumers to buy a product so that sales made by business owners experience an increase. Also, halal certification is a potentially useful branding and marketing mechanism for products and services. By understanding the factors on halal certification adoption for small and micro enterprises, the policymaker may know the level of acceptance on halal certification adoption for the small- and micro-enterprises. Some of Indonesia's development planning and direction documents have explicitly stated efforts to strengthen small businesses. Azqiara (2019) also argued that MSMEs could be interpreted as the development of a mainstay area to accelerate economic recovery to accommodate priority programs and development of various sectors and potentials, while small businesses are an increase in various efforts of community empowerment. There are groups of actors in the upstream-downstream chain who cannot accumulate capital in the four research cases. These groups include ceramic craftsmen and coconut sugar groups. Meanwhile, in the furniture industry, the second-level subcontracting relationship with the labor groups cannot accumulate capital. Another group that was found unable to raise capital was the rattan picking farmer group (Widyaningrum 2013).

\section{METHODS}

This research employed a qualitative approach. The implementation of preliminary activities in socialization activities was designed with P-IRT education activities and halal certification by the Indonesian Ulema Council in the Blitar Regency. In addition to the education process for MSME owners, this service activity also assists entrepreneurs who do not have a halal certificates in obtaining a halal certification.

Data collection methods used interviews and observations of 33 subjects who participated in the socialization of the importance of halal certificates. A total of 33 participants were asked the same questions in the context of the benefits of the outreach activity. The selection of 33 participants was tentative, meaning that it is adjusted to the conditions of MSMEs in Blitar City. The sampling technique used was snowball sampling, so that not all participants were interviewed when the answers submitted were relatively the same. We also conducted participant observations on socialization activities in community service activities about enthusiastically registering for halal certificates through questionnaires.

Data reduction was based on business owners' enthusiasm to register for a halal certificate after the socialization activity took place, evidenced by filling in the Halal Certificate Registration Form. The selected samples were 33 MSME owners. Business owners were interviewed with structured questions to determine the effectiveness of the previous socialization. The interview technique used snowball sampling to end the interview, and the data was deemed sufficient when the answers given by the research subject were saturated or were the same.

\section{RESULTS AND DISCUSSION}

\subsection{The motivation aspect}

Based on the community's problems regarding the effectiveness of the socialization of the MUI halal certificate for MSMEs, the enthusiasm of the owners of MSMEs in obtaining halal certificates 
is very good. It is shown from the results of the questionnaire filled out by 33 research subjects who are willing to fill out the MUI halal certificate registration form. Previous research by Agustina et al. (2019) revealed that, after the socialization in the form of counseling, SME players had a deeper understanding of the importance of halal certification in their food products, increased insight into the effect of halal certification on buyer satisfaction of their products, created prospects business, as well as obtained the formation of understanding and experience regarding the steps for applying for halal certification to The Institute for the Study of Food, Drugs and Cosmetics of the Indonesian Ulema Council or LPPOM MUI using Cerol services.

The counseling has included the latest information about consumer behavior and consumer trends in choosing the type of food product. With halal certification, it is expected to increase competitiveness among similar industries. Halal certified products can ensure that the products have good nutritional content, are hygienic, healthy, and do not contain ingredients that can endanger the health of consumers. In line with that, Basir et al. (2018) conclude about his Based on previous studies and findings, expected competitiveness can influence the food safety management system adoption (Rahman et al. 2016). The findings from Rahman et al. (2016) stated that when the managers considered and realized the sources of competitiveness, it resulted in the adoption of a food safety management system. Also, Fernando and Yusoff (2014) highlighted that top management support positively impacts the Malaysian food safety system's adoption. In line with that, Rahman et al. (2016) contended that top management support is a crucial factor in the adoption of any management system. For instance, Hamim et al. (2015) agreed that top management commitment is a critical success factor of quality management practice. Arpanutud et al. (2009) stated that top management commitment would influence food safety management systems' implementation. To confirm this (Arpanutud et al. 2009) also stated that top management in the firm will increase food safety management system adoption.

Based on the survey in a group of SME in Blitar, the owner of the SME's commitment is significant to halal certification adoption. The researchers concluded that top management plays an important role in ensuring that halal certification adoption works smoothly with many perspectives of the study and variety of research settings. Motivational factors are vital in halal certification due the commitment of higher management. By showing their commitment to halal certification adoption, the process of adoption is run more smoothly as management may provide time, money, and ideas in the adoption of the new policy. In inspiring the halal certification adoption, the study on the motivational factors is important because it provides significance to researchers, academics, and the industry by providing insight into the halal quality certification. Also, the study will add to the body of knowledge. Also, this paper provides valuable information for SME companies in Malaysia to adopt halal certification. The research project is expected to be a reference for future researchers and valuable in directing their focus, efforts, time, and resources on halal certification adoption. The community service activities explored the importance of P-IRT registration and ownership of halal certificates for food entrepreneurs to strengthen micro-businesses' existence. Through this educational activity, it is expected that more micro-business products have been registered with the health department and have a halal label so that the possibility to compete with products that have gone through the manufacturing process is very large. P-IRT can assist SMEs in matters of legal certainty and certainty about the quality of food products.

\subsection{Halal certificate registration constraints}

According to Maryati et al. (2016), the process of applying for a halal certificate is based on the current provisions of the LPPOM-MUI. Business actors must understand the requirements for halal certification and attend training in the halal assurance system and apply with a complete set of documents that includes: a list of products, a list of materials, and material documents; a product matrix, a manual of the halal assurance system, a diagrams process flow, an address list of production facilities; evidence of: halal policy dissemination, internal training, an internal audit, registeration for halal certification, monitoring pre-audits and payment of certification contracts, conducting audits, monitoring post-audits, having P-IRT/MD distribution permits, and possession 
of an MD distribution license for high-risk products. These requirements can be prepared by the business actor except the MD distribution permit from BPOM and IUI/IUMK from BPPTPM.

The long process of registering a halal certificate for a product at MUI has discouraged business owners. In fact, there are other obstacles faced by business owners, such as the costs incurred to prepare halal certificate registration documents. However, a very influential obstacle for SMEs involved in the Food and Beverages sector in registering for a halal certificate is the matter of halal raw materials made from animal elements. According to Maryati et al. (2016), the marketing authorizations problem in halal certificate registration is improving the competitiveness $(0.575)$ with assistance (0.321) from Badan Pengawas Obat dan Makanan (0.484). Factors that mostly influence the production facility (0.572) included raw material $(0.233)$, the attitude of enterprises (0.838), and legality (0.432). The best alternative strategies recommended are fostering good production (0.343), bureaucratic of marketing authorization accelerated and simplified (0.169), and intensive coaching $(0.153)$.

\section{CONCLUSION}

This research has uncovered the awareness of the importance of the ownership of letters, which significantly supports business strengthening. Business actors are very enthusiastic about participating in counseling activities about the ownership of halal certificates. This enthusiasm was evidenced by the number of participants who shared their obstacles and problems with the speakers. Apart from sharing activities, participants also asked a lot about the correct management procedures for halal certificates. On the other hand, the socialization's effectiveness, which shows good results, is inversely proportional to post-activity in the field, which has obstacles because of unresolved technical issues.

\section{REFERENCES}

Ade Rosilawati. 2011. "Pengaruh perkembangan Usaha Kecil dan Menengah terhadap Pertumbuhan Ekonomi pada Sektor UKM di Indonesia", Undergraduate Thesis, Yogyakarta.

Aisjah Girindra. 2008. "Dari sertifikasi Menuju Labelisasi Halal.” Jakarta: Pustaka Jurnal Halal.

Al-Qur'an, Surat Al-Baqarah (2) ayat 168-171. Al-Qur'an dan Terjemahan. Cetakan ke 7: Al-Mizan Publishing House.

Andriyani. 2019. Kajian Literatur pada Makanan dalam Perspektif Islam dan Kesehatan. Jurnal Kedokteran dan Kesehatan, Vol. 15, No. 2

Arpanutud, P., Keeratipibul, S., Charoensupaya, A., \& Taylor, E. 2009. Factors influencing food safety management system adoption in Thai food-manufacturing firms: Model development and testing. British Food Journal, 111(4), 367.

Azqiara. 2019. Pengertian UMKM Secara Umum dan Menurut Para Ahli Lengkap.

Backhouse, C. J., \& Mohamad, N. 2014. A framework for the development of Halal food products in Malaysia.

Elias, M.E., Othman, S. N., Yaacob, A. N., \& Saifudin, A. M. 2016. A Study of Halal Awareness and Knowledge Among Entrepreneur Undergraduates. International Journal of Supply Chain Management, 5(3), 147-152.

Fernando, Y., Ng, H.H. \& Yusoff, Y. 2014. Activities, motives and external factors influencing food safety management system adoption in Malaysia. Food Control, Vol. 41, pp. 69-75.

Kurth, L., \& Glasbergen, P. 2017. Serving a heterogeneous Muslim identity? Private governance arrangements of halal food in the Netherlands. Agriculture and Human Values, 34(1), 103-118.

MUI. 2014. Lembaga Pengkajian Pangan Obat-obatan dan kosmetik Majelis Ulama Indonesia.

MUI. INDHEX. 2018, Jalan Menuju Arus Baru Ekonomi Indonesia.

A. H., Zainuddin, Y., \& Thurasamy, R. 2015. Barriers and enablers in adopting of Halal warehousing. Journal of Islamic Marketing, 6 (3), 354-376.

MUI. 2019. Data Sertifikasi Halal LPPOM MUI 2012-2019.

Nurul Widyaningrum. 2013. Pola-pola Eksploitasi Terhadap Usaha Kecil. Banding: Aka tiga.

Maria Mohd Salleh. 2018. Motivational Factors for Halal Certification Adoption among Small and Micro Enterprises in Malaysia. Int. J Sup. Chain. Mgt. Vol. 7, No. 4, August 2018. page 391-396. 
Rahman, N. A., Yaacob, Z., \& Radzi, R. M. 2016. The Challenges Among Malaysian SME: A Theoretical Perspective. World, 6(3), 124-132.

Salikin, N., Ab Wahab, N., \& Muhammad, I. 2014. Strengths and Weaknesses among Malaysian SMEs: Financial Management Perspectives. Procedia-Social and Behavioral Sciences, 129, 334-340.

Shafie, S., \& Othman, M. N. 2006. Halal Certification: an intern ational marketing issues and challenges. In Proceeding at the International IFSAM VIIIth World Congress (pp. 28-30).

Sofyan Hasan. 2014. "Kepastian Hukum Sertifikasi dan Labelisasi halal Produk Pangan”. Jurnal Dinamika hukum, Vol. 14 No. 2.

Soon, J. M., Chandia, M. \& Regenstein, J. M. 2017. Halal integrity in the food supply chain. British Food Journal, 119(1), 39-51.

Talib, M. S., Abdul Hamid, A. B., \& Ai Chin, T. 2015. Motivations and limitations in implementing Halal food certification: a Pareto analysis. British Food Journal, 117(11), 2664-2705.

Undang-Undang Republik Indonesia Nomor 33 tahun 2014 tentang Jaminan Produk Halal, Jakarta: Hukum Online, 2014.

UU No. 8 Tahun 1999 tentang perlindungan konsumen.

UU No. 7 Tahun 1996 tentang Pangan. 